\title{
Supraglottic Cancer Pathologic Regional Lymph Nodes TNM Finding v6
}

National Cancer Institute

\section{Source}

National Cancer Institute. Supraglottic Cancer Pathologic Regional Lymph Nodes TNM

Finding v6. NCI Thesaurus. Code C64723.

A pathologic finding about one or more characteristics of suprag lottic cancer, following the rules of the TNM AJCC V6 classification system as they pertain to stag ing of regional lymph nodes. 